\title{
Pemilihan Profesi Akuntan: Pengaruh Persepsi Penghargaan Finansial, Pelatihan Profesional, Nilai-Nilai Sosial Dan Lingkungan Kerja (Studi Pada Mahasiswa Program Studi Akuntansi Fakultas Ekonomi dan Bisnis Universitas Muhammadiyah Tangerang)
}

\author{
Dirvi Surya Abbas ${ }^{(1)}$, \\ Universitas Muhammadiyah Tangerang \\ abbas.dirvi@gmail.com \\ Arry Eksandy (2), \\ Universitas Muhammadiyah Tangerang \\ arry.eksandy@yahoo.com \\ Mohamad Zulman Hakim ${ }^{(3)}$ \\ Universitas Muhammadiyah Tangerang \\ zulman.hakim@umt.ac.id
}

\section{Abstract}

This study aims to obtain evidence regarding the influence of Perception of Financial Awards, Professional Training, Social Values and Work Environment on the Selection of the Accounting Profession. This study uses purposive sampling and accidental sampling techniques and obtained a sample of 101 accounting students in 2016 taken in the academic year 2018/2019. Hypothesis testing in this study was conducted using multiple linear regression analysis.

The results of the first research hypothesis indicate that in the model there is a significant positive effect of the Perception of Financial Awards on the Accountant's Professional Selection, with the results of $t_{\text {count }} 3,517>t_{\text {table }} 1,985$ and sig. $0.001<0.05$, then the results of the second research hypothesis indicate that in the model there is a significant positive effect of Professional training on the Accountants Professional Selection, with $t_{\text {count }} 3,772>t_{\text {table }} 1,985$ and sig. 0,000 $<0.05$, then the results of the third research hypothesis show that in the model there is no significant effect of social values on the Professional Selection of Accountants, with $t_{\text {count }}-1.254<t_{\text {table }} 1,985$ and sig. 0.213>0.05, and then the results of the fourth research hypothesis indicate that in the model there is a significant positive effect of the Work Environment on the Professional Selection of Accountants, with $t_{\text {count }} 2.212>t_{\text {table }} 1.985$ and sig. $0.029<0.05$.

Keywords: Financial Awards, Professional Training, Social Values, Work Environment and Professional Selection of Accountants

\section{PENDAHULUAN}

Sumber

utama yang

menimbulkan ancaman pada akuntansi di generasi 4.0 adalah teknologi. Karena bagi generasi sekarang (milenial) tidak lepas dari yang namanya teknologi. Anak Generasi milenial dari lahir sudah mengenal tentang dengan perkembangan teknologi. Mereka banyak menghabiskan waktunya dengan berkomunikasi dan melakukan transaksi melalui jejaring internet. Pergeseran generasi inilah yang kemudian menyebabkan adanya beberapa pekerjaan yang akan tergantikan. Salah satu perkejaan yang terancam adalah profesi di bidang akuntansi. Contohnya saja di era milenial ini pembuatan laporan keuangan, sekarang sudah banyak perusahaan yang menggunakan software untuk menghemat biaya namun tetap akurat hasilnya. Isu ini sudah sangat beredar di masyarakat, terutama masyarakat yang bekerja atau studi di bagian akuntansi. Alhasil mereka harus mempersiapkan beberapa strategi dalam menghadapi tantangan tersebut. Sudah ada beberapa penelitian yang dilakukan bagiamana solusi menghadapinya. Solusi tersebut yaitu: Seorang akuntan tidak hanya dapat membuat sekedar laporan keuangan saja, namun harus mengetahui asal angka tersebut berasal. Seorang akuntan juga harus mampu menganalisis sebuah 
laporan keuangan, karena secanggih apapun teknologi tidak akan bisa memutuskan apa tindakan yang baik kedepannya yang akan dilakukan perusahaan. Setidaknya seorang akuntan harus mengerti beberapa Bahasa asing dan Bahasa teknologi. Akuntan harus mengerti menggunakan teknologi di zaman sekarang, agar seorang akuntan tersebut dapat mengimbangi kemajuan teknologi.

Bagi mahasiswa akuntansi, harus mempersiapkan diri dengan cara belajar Bahasa asing, mengikuti beberapa pelatihan teknologi dan pelatihan yang berbau akuntansi seperti pelatihan audit, pelatihan cara menganalisis laporan keuangan, dan lain-lain. Dengan demikian, jangan takut untuk menghadapi generasi 4.0, namun harus mempersiapkan diri secara matang untuk bersaing dengan teknologi. Teknologi hanya membantu seorang akuntan dalam mempersingkat waktu bukan menghilangkan pekerjaan. Karena tidak semua pekerjaan akuntan dapat digantikan oleh teknologi. Contohnya saja, dalam pekerjaan audit ada menggunakan software yang bernama Continuous audit. Software ini membantu seorang audit untuk membuat laporan audit. Namun, ada beberapa hal yang tidak bisa dilakukan oleh software tersebut, contohnya adalah software ini tidak dapat mengubah beberapa perubahan regulasi atau aturan-aturan pemerintah dan standar akuntansi keuangan yang berlaku. Software ini juga membutuhkan dana yang besar untuk mendapatkannya, selain itu ada beberapa kesulitan yang dialami saat menggunakan alat ini yaitu saat ingin memperoleh data yang besar dan kompleks dengan keuangan perusahaan yang bermacam-macam. Nah inilah peran manusia dalam menggunakan kecerdasannya untuk menutupi kelemahan yang ada di software tersebut. Walaupun teknologi sudah memiliki sistem yang baik dalam menyimpan data yang sangat besar, namun untuk pengolahan data pastinya akan tetap membutuhkan pemikiran, rasional, dan logika manusia dalam melakukan analisanya. Hal ini yang dapat diingat "manusialah yang membuat teknologi, berarti manusia lebih pintar dan tidak akan tergantikan oleh teknologi". Maka bagi seseorang yang mempunyai profesi di akuntansi atau mahasiswa yang menempu jurusan akuntansi, generasi 4.0 yang akan dihadapi jangan dijadikan ancaman namun jadikanlah sebagai peluang.

Berikut adalah data lulusan sarjana akuntansi per tahun di negara-negara ASEAN

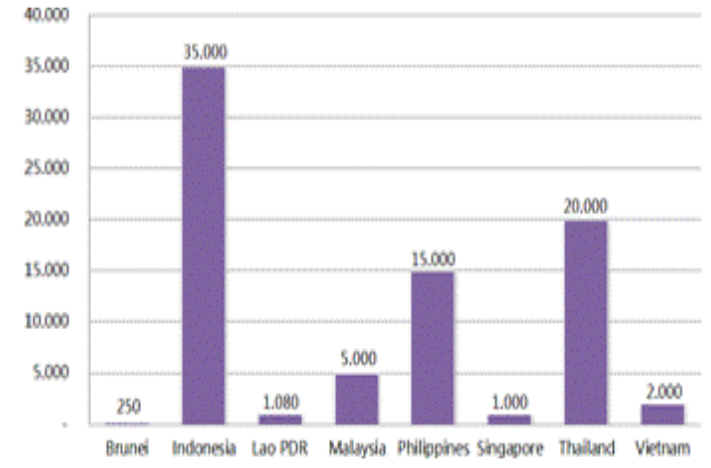

Menurut (R Antares, 2019) Ratarata dalam setahun, lulusan S1 Akuntasi dari berbagai perguruan tinggi di Indonesia sebanyak 35.000 orang Sedangkan akuntan yang sudah bersertifikat CPA dari IAPI sebanyak 2.064 orang. Jumlah yang lumayan besar. Namun, jika dibanding dengan negara-negara ASEAN, ternyata jumlah akuntan di Indonesia tergolong minim dibanding Singapura, Malaysia, Philipina dan Thailand. Revolusi Industri 4.0 memberi kesempatan bagus bagi lulusan akuntansi. Pemerintah sudah memberikan payung hukum dengan UU nomor 5/2011 tentang Akuntan Publik. Bagi akuntan yang sudah mengantongi Certified Public Accountant (CPA) bisa bekerja di negara ASEAN karena berstandar internasional. Persoalannya, jumlah akuntan yang sudah memiliki CPA masih sedikit. kondisi ini menjadi peluang mengingat pasar jasa sangat besar didalam era industri 4.0. Di sisi lain menjadi tantangan dalam berkompetisi dengan akuntan dari negara-negara tetangga. 
Akuntan dari negara tetangga bisa masuk bekerja di Indonesia.

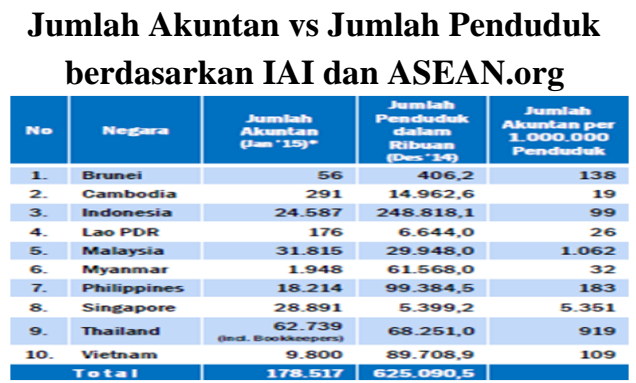

Berdasarkan tabel diatas dapat ditentukan urutan negara dengan jumlah akuntan terbanyak dibandingkan dengan jumlah penduduknya yang pertama adalah Singapura, lalu yang kedua Malaysia, lalu yang ketiga Thailand, lalu yang keempat Brunei, lalu yang kelima Philipina, lalu yang keenam Vietnam, lalu yang ketujuh Indonesia, lalu yang kedelapan Myanmar, lalu yang kesembilan Laos dan terakhit Kamboja. Pentingnya akan kebutuhan akuntan di indonesia dikarenakan oleh adanya faktor-faktor Regulasi dan best practices yakni tentang ketentuan yang diatur dalam regulasi (UU atau regulasi lainnya) dan best practices internasional. Lalu, adanya Kebutuhan laporan keuangan yang andal dalam meningkatkan kepercayaan stakeholders, khususnya investor dan konsumen. berikutnya, karena adanya suatu kebutuhan transparansi dan akuntabilitas yang sudah menjadi tuntutan stakeholders. Lalu berikutnya, karena adanya perkembangan belanja negara dan bisnis yang makin berkembang sehingga membutuhkan akuntan yang lebih banyak. Dan terakhir, karena adanya sautu organisasi bisnis yang belum tersentuh di Indonesia, seperti UMKM yang belum tersentuh oleh praktik akuntansi yang benar.

Berdasarkan hasil penelitian yang dilakukan oleh (Zaid, 2015), (Iswahudin, 2015), (Riyanto, 2015)dan (Choirunisa, 2017), dalam hasil penelitian mereka tentang faktor- faktor yang mempengaruhi mahasiswa akuntansi berkarir menjadi akuntan publik menemukan hasil bahwa minat mahasiswa akuntansi berkarir menjadi akuntan publik salah satunya dipengaruhi oleh penghargaan finansial.
Pendapatan atau penghargaan finansial selalu menjadi salah satu hal yang menjadi pertimbangan pemilihan profesi menjadi akuntan, hal tersebut terjadi karena Mahasiswa akuntansi yang memilih karir menjadi akuntan publik lebih mengharapkan penghargaan finansial/gaji gaji awal yang lebih tinggi, kenaikan gaji yang cepat, serta jaminan masa depan karena hal tersebut dapat memberikan kepuasan bagi mereka atas kinerja yang sudah diberikannya kepada lembaga atau organisasi. Namun berbeda dengan hasil penelitian yang dilakukan oleh (Naminingsih, 2018) dan (Rahmawati, 2014) yang menyatakan bahwa penghargaan financial tidak berpengaruh terhadap mahasiswa akuntansi dalam berkarir menjadi akuntan publik. Menurut (Naminingsih, 2018) Hal tersebut terjadi karena keinginan untuk memperoleh gaji atau pendapatan tertentu yang sesuai dengan bidang kerja mereka tampaknya bukan menjadi motivasi mahasiswa dalam memilih karirnya untuk menjadi akuntan. karena karir selain menjadi akuntan di saat ini dinilai cukup lebih menjanjikan dalam hal pendapatan yang akan diterimanya.

Selain financial yang memotivasi mahasiswa akuntansi dalam memilih karir untuk menjadi akuntan publik. diduga kuat dapat dikatakan menjadi faktor lain mahasiswa akuntansi dalam memotivasi berkarir menjadi akuntan publik. Pelatihan profesional merupakan suatu bentuk pendidikan yang memiliki tujuan untuk memperbaiki keterampilan dan kemampuan yang tinggi, berpegang teguh pada nilai moral, dan ahli pada bidangnya, yang diharapkan mampu menunjang pekerjaan dan meningkatkan kualitas seseorang dalam bekerja guna memenuhi keperluan hidupnya. Contoh pelatihan yang diharapkan antara lain pelatihan sebelum dan selama bekerja, pembelajaran berkelanjutan, dan adanya pengakuan professional.

Berdasarkan hasil penelitian yang dilakukan oleh (Naminingsih, 2018) Pelatihan profesional berpengaruh signifikan terhadap pemilihan karir Akuntan Publik. Hal ini mengartikan 
mahasiswa bahwa suatu organisasi yang baik akan memberikan suatu pembekalan dan peningkatan keahlian melalui pelatihan professional yang diberikan untuk calon karyawan ataupun karyawan tetap merupakan, serta hal tersebut pastinya akan memberikan dampak secara signifikan bagi karyawan serta calon karyawan. Profesi yang memiliki pelatihan professional yang baik akan menjadi suatu daya tarik bagi profesi tersebut. Hal ini sesuai dengan hasil penelitian Zulaikha (2013) yang menyatakan bahwa pelatihan professional berpengaruh signifikan terhadap pemilihan karir Akuntan Publik. Dan hasil penelitian ini tidak sejalan dengan hasil penelitian yang dilakukan oleh (Rahmawati, 2014), yang menyatakan bahwa pelatihan professional tidak berpengaruh signifikan terhadap pemilihan karir Akuntan Publik.

Lalu, variabel lain yang di duga mempengaruhi mahasiswa akuntansi dalam memilih karir untuk menjadi akuntan publik adalah Nilai-nilai sosial. menurut (Efendi, 2018) Nilai-nilai sosial merupakan suatu kemampuan seseorang di dalam masyarakat yang dapat diterima dan digunakan untuk merumuskan apa yang benar dan apa yang penting. Keberadaan seseorang di dalam kehidupan sosial selalu menjadi perhatian masyarakat, baik dari segi aktivitas dan pekerjaan yang diterima masyarakat, interaksi dengan masyarakat, dan sebagai kontrol sosial ditengah masyarakat.

Menurut hasil penelitian yang dilakukan oleh (Ambari dan Ramantha, 2017), (Riyanto, 2015) dan (Efendi, 2018) menyatakan bahwa nilai-nilai sosial berpengaruh signifikan terhadap minat mahasiswa akuntansi berkarir menjadi akuntan publik. Hal ini bisa dikarenakan nilai-nilai sosial dipertimbangkan dalam memilih Profesi Akuntan Publik. Mahasiswa akuntansi yang memilih karir sebagai akuntan publik memandang tugas kerja dalam akuntan publik lebih sering berinteraksi dengan klien atau pihak-pihak eksternal. Dengan ini akuntan publik bisa menambah rekan/kawan dan bisa menambah pengetahuannya di luar bidang akuntansi karena interaksi yang dilakukan sewaktu bekerja tidak hanya dengan sesama akuntan saja, akan tetapi juga dengan para ahli profesional dibidang lain. Namun berbeda dengan hasil penelitian yang dilakukan oleh (Sulistyawati, 2013) menyatakan bahwa adanya perbedaan pandangan yang signifikan di antara mahasiswa yang memilih karir sebagai akuntan publik, akuntan pendidik, akuntan pemerintah, dan akuntan perusahaan mengenai nilai-nilai sosial. Mahasiswa yang memilih karir sebagai akuntan public dan akuntan pendidik menganggap bahwa karir tersebut mereka punya kesempatan lebih banyak untuk berinteraksi dengan orang lain. Mahasiswa menganggap akuntan pemerintah kurang memberi kepuasaan pribadi karena kurang bebas dalam mengekspresikan kemampuan dan kreativitasnya. Karir sebagai akuntan perusahaan dianggap kurang memberi perhatian pada perilaku individu. Lalu, variabel lain yang di duga mempengaruhi mahasiswa akuntansi dalam memilih karir untuk menjadi akuntan publik selain diatas adalah variabel Lingkungan kerja. Hal tersebut merupakan lingkungan disekitar seseorang yang dapat mempengaruhi kinerja seseorang. Lingkungan kerja yang baik akan meningkatkan kinerja sesorang dalam bekerja. Kriteria yang diharapkan di dalam lingkungan kerja antara lain hubungan yang baik kepada sesama rekan kerja dan atasan, dan lingkungan fisik yang nyaman.Pada dasarnya persepsi merupakan suatu proses pemberian makna dengan menyimpulkan informasi dan menafsirkannya. Sebagai mahasiswa sudah sewajibnya memiliki pertimbangan berdasarkan persepsi yang dimilikinya akan faktor yang mempengaruhi akan pemilihan profesi akuntan. Faktor-faktor yang perlu dipertimbangkan diatas, secara tidak langsung akan mempengaruhi mahasiswa program studi akuntansi terhadap pemilihan profesi sebagai akuntan. Pada dasarnya penelitian yang dilakukan di sini, dimotivasi oleh hal-hal yang dikemukakan di depan. Ada dua motivasi yang mendasari penelitian ini. (1) banyaknya lulusan S1 Akuntasi dari berbagai perguruan tinggi di Indonesia yaitu sebanyak 35.000 orang, namun yang berprofesi menjadi akuntan yang sudah bersertifikat CPA dari IAPI hanya sebanyak 
2.064 orang. (2) jumlah akuntan di Indonesia tergolong minim dibanding Singapura, Malaysia, Philipina dan Thailand.

\section{KAJIAN LITERATUR DAN PENGEMBANGAN HIPOTESIS}

Perencanaan dan pemilihan profesi merupakan hal yang penting untuk dipertimbangkan oleh mahasiswa akuntansi untuk berkarir disaat nanti setelah lulus dari bangku kuliah. Berikut adalah perumusan hipotesis terkait penelitian diatas.

\section{Pengaruh Persepsi Penghargaan Finansial Terhadap Pemilihan Profesi Akuntan}

bahwa persepsi adalah peristiwa pemberian makna yang didahului oleh penginderaan, yang diperoleh dengan menyimpulkan informasi dan menafsirkan pesan, sehingga individu menyadari, mengerti, dan memahami apa yang diinderanya. Mahasiswa akuntansi memiliki peluang untuk berprofesi sebagai akuntan, sehingga diharapkan telah memahami bidang profesi akuntansi yang akan dipilihnya. Pemahaman mahasiswa akuntansi memandang profesi sebagai akuntan akan memberikan kepuasan melalui penghargaan finansial, maka akan meningkatkan kemungkinan bagi mahasiswa akuntansi untuk memilih profesi akuntan. Sebaliknya, jika mahasiswa akuntansi memandang profesi sebagai akuntan tidak memberikan kepuasan melalui penghargaan finansial, maka akan menurunkan kemungkinan bagi mahasiswa akunansi untuk memilih profesi akuntan. Sehingga dapat disimpulkan bahwa semakin tinggi penghargaan finansial yang akan didapat, maka kemungkinan bagi mahasiswa akuntansi untuk memilih profesi akuntan juga semakin tinggi.Menurut hasil penelitian yang dilakukan oleh (Zaid, 2015), (Iswahudin, 2015), (Riyanto, 2015) dan (Choirunisa, 2017), menyatakan bahwa Persepsi Penghargaan Financial berpengaruh Positif terhadap Pemilihan Profesi Akuntan, namun berbeda dengan hasil penelitian yang dilakukan oleh (Naminingsih, 2018) dan (Rahmawati, 2014) yang menyatakan bahwa penghargaan financial tidak berpengaruh terhadap mahasiswa akuntansi dalam berkarir menjadi akuntan publik. maka hipotesis yang diajukan adalah sebagai berikut:

$\mathrm{H}_{1}$ : Persepsi Penghargaan Financial berpengaruh terhadap Pemilihan Profesi Akuntan.

\section{Pengaruh Pelatihan Profesional Terhadap Pemilihan Profesi Akuntan \\ Pelatihan profesional adalah kegiatan} pendidikan yang dilakukan, yang berguna untuk memperbaiki keterampilan agar memiliki kemampuan yang tinggi dan berpegang teguh kepada nilai moral, dan ahli sesuai dengan bidangnya. Apabila mahasiswa akuntansi sering mendapatkan pelatihan profesional, maka akan meningkatkan kemungkinan bagi mahasiswa akuntansi untuk memilih profesi akuntan. Sebaliknya, jika mahasiswa akuntansi tidak sering mendapatkan pelatihan profesional, maka akan menurunkan kemungkinan bagi mahasiswa akuntansi untuk memilih profesi akuntan. Sehingga dapat disimpulkan bahwa semakin sering mendapatkan pelatihan profesional, maka kemungkinan bagi mahasiswa akuntansi untuk memilih profesi akuntan juga semakin tinggi.

Hasil dari penelitian Kharismawati (2015) mendukung teori penelitian ini, Hasil dari pelatihan professional berpengaruh signifikan terhadap pemilihan karir menjadi akuntan, yang mengartikan bahwa banyaknya pelatihan yang diberikan kepada para akuntan mana ia bekerja, maka hal tersebut akan mampu memperbaiki suatu penugasan dari berbagai keterampilan dan teknik pelaksanaan pekerjaan tertentu.

$\mathrm{H}_{2}$ : Pelatihan Profesional berpengaruh terhadap Pemilihan Profesi Akuntan.

\section{Pengaruh Persepsi Nilai-nilai Sosial Terhadap Pemilihan Profesi Akuntan}

Keterkaitan antara teori TPB dengan Nilai-nilai sosial adalah gambaran akan pengaruh sosialnya (social influence) atau juga yang disebut sebagai norma subjektif (subjective norm). mahasiswa akuntansi merasa nilai-nilai sosial profesi akuntan dinilai baik dalam masyarakat, maka akan meningkatkan kemungkinan bagi mahasiswa akuntansi untuk memilih profesi akuntan. Sebaliknya, jika mahasiswa akuntansi merasa nilai-nilai sosial profesi akuntan tidak dinilai baik, maka akan 
menurunkan kemungkinan bagi mahasiswa akuntansi untuk memilih profesi akuntan. Sehingga dapat disimpulkan bahwa semakin nilai-nilai sosial profesi akuntan dinilai baik, maka kemungkinan bagi mahasiswa akuntansi untuk memilih profesi akuntan juga semakin tinggi.

Menurut hasil penelitian yang dilakukan oleh (Ambari dan Ramantha, 2017), (Riyanto, 2015) dan (Efendi, 2018) menyatakan bahwa nilai-nilai sosial berpengaruh signifikan terhadap minat mahasiswa akuntansi berkarir menjadi akuntan publik. Namun berbeda dengan hasil penelitian yang dilakukan oleh (Sulistyawati, 2013) menyatakan bahwa adanya perbedaan pandangan yang signifikan di antara mahasiswa yang memilih karir sebagai akuntan publik, akuntan pendidik, akuntan pemerintah, dan akuntan perusahaan mengenai nilai-nilai sosial. maka hipotesis yang diajukan adalah sebagai berikut:

$\mathrm{H}_{3}$ : Persepsi Nilai-Nilai Sosial berpengaruh terhadap Pemilihan Profesi Akuntan.

\section{Pengaruh Lingkungan Kerja Terhadap Pemilihan Profesi Akuntan}

Lingkungan kerja adalah segala sesuatu yang berada disekitar karyawan yang dapat mempengarui karyawan, baik secara langsung maupun tidak langsung. Apabila mahasiswa akuntansi merasa nyaman dengan lingkungan kerja akuntan, maka akan meningkatkan kemungkinan bagi mahasiswa akuntansi untuk memilih profesi akuntan. Sebaliknya, jika mahasiswa akuntansi merasa tidak nyaman dengan lingkungan kerja akuntan, maka akan menurunkan kemungkinan bagi mahasiswa akuntansi untuk memilih profesi akuntan. Sehingga dapat disimpulkan bahwa semakin nyaman lingkungan kerja akuntan, maka kemungkinan bagi mahasiswa akuntansi untuk memilih profesi akuntan juga semakin tinggi.

Hasil dari penelitian ini mendukung penelitian dari Kharismawati (2015) Hasil dari penelitian tersebut menyatakan bahwa semakin baik lingkungan kerja maka motivasi pemilihan karier sebagai akuntan akan semakin tinggi. Hal ini dikarenakan dalam pekerjaan tentu perlu didukung oleh lingkungan kerja yang memadai yang memsupport aktivitas keseharian dalam bekerja serta tugas-tugas yang amanahakannya. maka hipotesis yang diajukan adalah sebagai berikut:

$\mathrm{H}_{4}$ : Lingkungan Kerja berpengaruh terhadap Pemilihan Profesi Akuntan.

\section{METODE PENELITIAN}

Populasi dalam penelitian ini adalah mahasiswa akuntansi angkatan 2016 di Universitas Universitas Muhammadiyah Tangerang sebanyak 101 mahasiwa yang diambil pada tahun akademik 2018/2019. Adapun teknik pengambilan sampel dalam penelitian ini adalah purposive accidental sampling dengan kriteria mahasiswa angkatan 2016 dan telah menempuh mata kuliah Auditing. Penyebaran kuesioner dilakukan secara langsung pada mahasiswa Universitas Muhammadiyah Tangerang Fakultas ekonomi \& bisnis Program studi akuntansi. Penyebaran kuesioner ini dilaksanakan dengan mendatangi responden, dan membagikan angket berisi daftar pernyataan yang telah disusun oleh peneliti. Responden dipilih menggunakan metode non probability sampling, yaitu siapa saja yang secara kebetulan/incidental bertemu dengan peneliti dapat digunakan sebagai sampel, bila dipandang orang yang kebetulan ditemui cocok sebagai sumber data. Jenis data penelitian ini adalah data primer yang merupakan persepsi mahasiswa akuntansi mengenai faktor-faktor yang mempengaruhi pemilihan karir yang diperoleh secara langsung melalui penyebaran kuesioner secara tertulis kepada responden penelitian, yaitu mahasiswa program studi akuntansi

\section{Pemilihan Profesi Akuntan (Y)}

Pemilihan profesi akuntan adalah pemahaman akan segala pengaruh interaksi social dan budaya, teman sejawat, keluarga, serta orang yang dipandang dewasa, sehingga mengarahkan diri pada suatu tingkat untuk memilih menentukan pekerjaan yang seusuai dengan keahlian dibidang akuntansi, serta telah menempuh program profesi akuntansi dan telah lulus ujian sertifikasi. Dalam pertanyaan yang disampaikan pada kuesioner dalam Pemilihan Profesi Akuntan adalah Indikator dalam variabel ini, yaitu kebutuhan 
fisiologis, kebutuhan rasa aman (safety need), kebutuhan sosial (social need), kebutuhan penghargaan (esteem need), kebutuhan aktualisasi diri (self actualization need). Instrumen yang dipakai untuk mengukur suatu Pemilihan Profesi Akuntan terdiri dari 14 butir pertanyaan.

\section{Penghargaan Finansial $\left(\mathbf{X}_{1}\right)$}

Penghargaan finansial adalah Suatu upaya yang digunakan oleh suatu organisasi untuk menstimulan kinerja diri personel sehingga memotivasi sebagai daya tarik utama dalam tujuan bekerja. Dalam pertanyaan yang disampaikan pada kuesioner dalam Penghargaan Finansial adalah dengan indikator dalam variabel ini yaitu gaji, bonus, tunjangan, dan dana pensiun. Instrumen yang dipakai untuk mengukur suatu Pemilihan Profesi Akuntan terdiri dari 7 butir pertanyaan.

\section{Pelatihan Profesional $\left(\mathbf{X}_{2}\right)$}

Pelatihan profesional adalah suatu kegiatan pendidikan yang dilakukan, yang berguna untuk memperbaiki keterampilan agar memiliki kemampuan yang tinggi dan berpegang teguh kepada nilai moral, dan ahli sesuai dengan bidangnya. Pengukuran variabel ini dengan menggunakan kuesioner, dengan indikator yaitu pelatihan sebelum kerja dan selama kerja, pembelajaran berkelaanjutan, dan adanya pengakuan profesional.

\section{Nilai-Nilai Sosial $\left(\mathbf{X}_{\mathbf{3}}\right)$}

Nilai-nilai sosial adalah interaksi individu dalam bermasyarakat dengan norma-norma yang berlaku dan dijadikan sebagai dasar perumusan apa yang benar dan apa yang penting. Dalam pertanyaan yang disampaikan pada kuesioner dalam Nilai-nilai sosial adalah dengan indikator dalam variable ini dengan indikator yaitu nilai sosial yang tinggi (penerimaan masyarakat yang baik) terhadap pekerjaan, berinteraksi dengan masyarakat, dan kontrol sosial. Instrumen yang dipakai untuk mengukur suatu Pemilihan Profesi Akuntan terdiri dari 7 butir pertanyaan.

\section{Lingkungan Kerja $\left(\mathbf{X}_{4}\right)$}

Lingkungan kerja adalah segala sesuatu yang berada di sekitar karyawan yang dapat mempengaruhi karyawan, baik secara langsung maupun tidak langsung. Pengukuran variabel ini dengan menggunakan kuesioner, dengan indikator yaitu hubungan kerja antar sesama karyawan dan atasan, dan lingkungan fisik tempat pegawai bekerja.

\section{METODE ANALISIS DATA Uji Validitas}

Uji validitas dilakukan kepada instrumen Persepsi penghargaan finansial, pelatihan profesional, nilai-nilai sosial, lingkungan kerja dan pemilihan karir.

Berdasarkan hasil uji validitas persepsi penghargaan finansial diketahui $\mathrm{r}$ hitung terendah 0,303 dan $\mathrm{r}$ hitung tertinggi $0,834 \mathrm{r}$ tabel pada tingkat kesalahan $5 \%$ dengan jumlah responden sebanyak 101 mahasiswa. Maka dapat diketahui nilai $r$ tabel sebesar 0.1956 . hal tersebut menunjukkan $r$ hitung terendah > $\mathrm{r}$ tabel, sehingga butir instrumen tersebut dinyatakan valid. butir instrumen pada $r$ hitung terendah selanjutnya dapat dinyatakan valid. Berdasarkan Hasil uji tersebut, diperoleh kesimpulan yaitu 7 Item pertanyaan terntang penghargaan financial dinyatakan valid.

Berdasarkan hasil uji validitas persepsi penghargaan finansial diketahui $\mathrm{r}$ hitung terendah 0,310 dan $r$ hitung tertinggi $0,740 \mathrm{r}$ tabel pada tingkat kesalahan $5 \%$ dengan jumlah responden sebanyak 101 mahasiswa. Maka dapat diketahui nilai $r$ tabel sebesar 0.1956. hal tersebut menunjukkan $r$ hitung terendah > $\mathrm{r}$ tabel, sehingga butir instrumen tersebut dinyatakan valid. butir instrumen pada $r$ hitung terendah selanjutnya dapat dinyatakan valid. Berdasarkan Hasil uji tersebut, diperoleh kesimpulan yaitu 7 Item pertanyaan tentang Pelatihan Profesional dinyatakan valid.

Berdasarkan hasil uji validitas Nilainilai sosial diketahui $r$ hitung terendah 0,328 dan $\mathrm{r}$ hitung tertinggi $0,643 \mathrm{r}$ tabel pada tingkat kesalahan $5 \%$ dengan jumlah responden sebanyak 101 mahasiswa. Maka dapat diketahui nilai $r$ tabel sebesar 0.1956. hal tersebut menunjukkan $r$ hitung terendah $>\mathrm{r}$ tabel, sehingga butir instrumen tersebut dinyatakan valid. butir instrumen pada $r$ hitung terendah selanjutnya dapat dinyatakan valid. Berdasarkan Hasil uji tersebut, diperoleh kesimpulan yaitu 5 Item pertanyaan tentang Nilai-nilai sosial dinyatakan valid. 
Berdasarkan hasil uji validitas Lingkungan kerja diketahui $r$ hitung terendah 0,384 dan $\mathrm{r}$ hitung tertinggi $0,702 \mathrm{r}$ tabel pada tingkat kesalahan $5 \%$ dengan jumlah responden sebanyak 101 mahasiswa. Maka dapat diketahui nilai $r$ tabel sebesar 0.1956. hal tersebut menunjukkan $r$ hitung terendah > $r$ tabel, sehingga butir instrumen tersebut dinyatakan valid. butir instrumen pada $r$ hitung terendah selanjutnya dapat dinyatakan valid. Berdasarkan Hasil uji tersebut, diperoleh kesimpulan yaitu 4 Item pertanyaan tentang Lingkungan Kerja dinyatakan valid.

Berdasarkan hasil uji validitas Pemilihan Profesi Akuntan diketahui $r$ hitung terendah 0,522 dan $r$ hitung tertinggi $0,786 \mathrm{r}$ tabel pada tingkat kesalahan $5 \%$ dengan jumlah responden sebanyak 101 mahasiswa. Maka dapat diketahui nilai $\mathrm{r}$ tabel sebesar 0.1956. hal tersebut menunjukkan $\mathrm{r}$ hitung terendah $>\mathrm{r}$ tabel, sehingga butir instrumen tersebut dinyatakan valid. butir instrumen pada $r$ hitung terendah selanjutnya dapat dinyatakan valid. Berdasarkan Hasil uji tersebut, diperoleh kesimpulan yaitu 10 Item pertanyaan tentang Pemilihan Profesi Akuntan dinyatakan valid.

\section{Uji Reabilitas}

Dimana hasil dari perhitungan Alpha Cronbach's tersebut kemudian dikonsultasikan dengan ketentuan bahwa suatu variabel dikatakan variabel jika memberikan nilai Alpha Cronbach's $>0,60$ (Ghozali, 2011).

\begin{tabular}{l|c|r|l}
\multicolumn{4}{c}{ Hasil Uji Reabilitas } \\
\hline \multicolumn{1}{c|}{ Variabel } & $\begin{array}{c}\text { Jumlah Butir } \\
\text { Pertanyaan }\end{array}$ & $\begin{array}{c}\text { Cronbach's } \\
\text { Alpha }\end{array}$ & Keterangan \\
\hline Persepsi Penghargaan Finansial & 7 Butir & 0,755 & Reliabel \\
\hline Pelatihan Profesional & 7 Butir & 0,756 & Reliabel \\
\hline Nilai-Nilai Sosial & 5 Butir & 0,650 & Reliabel \\
\hline Lingkungan Kerja & 4 Butir & 0.648 & Reliabel \\
\hline Pemilihan Profesi Akuntan & 10 Butir & 0,765 & Reliabel \\
\hline
\end{tabular}

Sumber: Data diolah

Tabel diatas menunjukkan nilai cronbach's alpha atas variabel Persepsi Penghargaan Finansial sebesar 0,755, Pelatihan Profesional sebesar 0,756, NilaiNilai Sosial sebesar 0,650, Lingkungan Kerja sebesar 0,648 dan Pemilihan Profesi
Akuntan sebesar 0,765. Dengan demikian, dapat disimpulkan bahwa pernyataan dalam kuesioner ini reliabel karena mempunyai nilai cronbach's alpha lebih besar dari 0,60. Hal ini menunjukkan bahwa setiap item pernyataan yang digunakan akan mampu memperoleh data yang konsisten yang berarti bila pernyataan itu diajukan kembali akan diperoleh jawaban yang relatif sama dengan jawaban sebelumnya.

\begin{tabular}{l|c|c|c|c|c}
\hline & N & Min & Max & Mean & $\begin{array}{c}\text { Std. } \\
\text { Deviation }\end{array}$ \\
\hline Persepsi Penghargaan Finansial & 101 & 21 & 28 & 25.88 & 2.074 \\
Pelatihan Profesional & 101 & 15 & 28 & 23.80 & 2.631 \\
Nilai-Nilai Sosial & 101 & 15 & 20 & 17.07 & 1.235 \\
Lingkungan Kerja & 101 & 12 & 16 & 13.77 & 1.038 \\
Pemilihan Profesi Akuntan & 101 & 34 & 56 & 44.71 & 6.569 \\
Valid N (listwise) & 101 & & & & \\
\hline
\end{tabular}

Tabel diatas menjelaskan bahwa pada variabel Persepsi Penghargaan Finansial jawaban minimum responden sebesar 21 dan maksimum sebesar 28 , dengan rata-rata total jawaban 25,88 dan standar deviasi sebesar 2,074. Variabel Pelatihan Profesional jawaban minimum responden sebesar 15 dan maksimum sebesar 28 , dengan rata-rata total jawaban 23,80 dan standar deviasi sebesar 2,631. Variabel Nilai-Nilai Sosial jawaban minimum responden sebesar 15 dan maksimum sebesar 20, dengan rata-rata total jawaban 17,07 dan standar deviasi sebesar 1,235. Variabel Lingkungan Kerja jawaban minimum responden sebesar 12 dan maksimum sebesar 16, dengan rata-rata total jawaban 13,77 dan standar deviasi sebesar 1,038. Pada variabel Pemilihan Profesi Akuntan minimum jawaban responden sebesar 34 dan maksimum sebesar 56, dengan rata-rata total jawaban 44,71 dan standar deviasi sebesar 6,569.

\section{Uji Hipotesis \\ Uji Regresi Linier Berganda}

$$
\mathrm{Y}=\mathrm{a}+\mathrm{b} 1 \mathrm{X} 1+\mathrm{b} 2 \mathrm{X} 2+\mathrm{b} 3 \mathrm{X} 3+\mathrm{b} 4 \mathrm{X} 4+\mathrm{e}
$$

\section{Dimana :}

$\begin{array}{ll}\mathrm{a} & : \text { Konstanta } \\ \mathrm{b} 1, \mathrm{~b} 2, \mathrm{~b} 3, \mathrm{~b} 4 & : \text { Koefesien regresi } \\ \mathrm{Y} & : \text { Pemilihan Profesi Akuntan } \\ \mathrm{X} 1 & : \text { Persepsi Penghargaan } \\ & \text { Finansial }\end{array}$




$\begin{array}{ll}\text { X2 } & \text { : Pelatihan Profesional } \\ \text { X3 } & \text { : Nilai-nilai Sosial } \\ \text { X4 } & \text { : Lingkungan Kerja } \\ \mathrm{e} & \text { : Error }\end{array}$

\section{HASIL DAN PEMBAHASAN}

\section{Hasil Analisis Profil Responden}

Dari hasil pengolahan demografi perihal Gender responden, didapatkan hasil bahwa diketahui terdapat 53 responden adalah berjenis kelamin laki-laki, sedangkan 43 responden lainnya berjenis kelamin perempuan. Lalu berdasarkan usia responden rata-rata berusia kurang dari 20 tahun ada sebanyak 6 responden, 30 responden berusia 21 tahun, 38 responden berusia 22 tahun, lalu 6 responden berusia 23 tahun. lalu 19 responden berusia 25 tahun.

\section{Hasil Analisis Uji Normalitas}

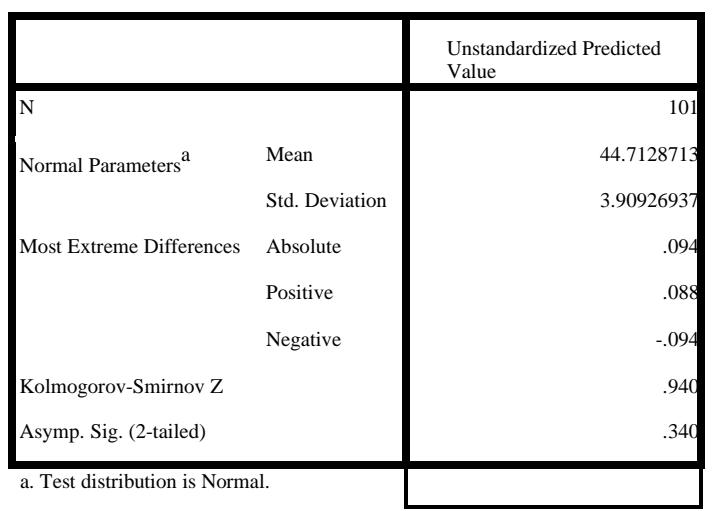

Hasil output dari uji normalitas pada tabel diatas memperlihatkan bahwa nilai signifikansi Kolmogorov-Smirnov sebesar 0,340, ini menunjukan bahwa nilai signifikansi diatas 0,05 sehingga dapat disimpulkan data pada kuesioner mempunyai distribusi normal.

\section{Hasil Analisis Uji Multikolinieritas}

\begin{tabular}{l|c|c}
\hline \multicolumn{1}{c|}{ Variabel } & Tolerance & VIF \\
\hline \hline Persepsi Penghargaan Finansial & .810 & 1.210 \\
\hline Pelatihan Profesional & .736 & 1.311 \\
\hline Nilai-nilai Sosial & .926 & 1.080 \\
\hline Lingkungan Kerja & .998 & 1.002 \\
\hline
\end{tabular}

Berdasarkan tabel diatas dapat dilihat bahwa nilai tolerance dari variabel Persepsi Penghargaan Finansial sebesar 0,810 lebih besar dari 0,1 , dengan nilai VIF sebesar
1,210 lebih kecil dari 10, untuk nilai tolerance dari variabel Pelatihan Profesional sebesar 0,736 lebih besar dari 0,1 , dengan nilai VIF sebesar 1,311 lebih kecil dari 10. Lalu, Nilai-Nilai Sosial sebesar 0,926 lebih besar dari 0,1, dengan nilai VIF sebesar 1,080 lebih kecil dari 10 . Dan Lingkungan Kerja sebesar 0,998 lebih besar dari 0,1 , dengan nilai VIF sebesar 1,002 lebih kecil dari 10. Dari hasil tersebut dapat disimpulkan variabel Persepsi Penghargaan Finansial, Pelatihan Profesional, Nilai-Nilai Sosial dan Lingkungan Kerja tidak mengalami multikolinearitas.

\section{Hasil Analisis Uji Heteroskedastisitas seatterplot}

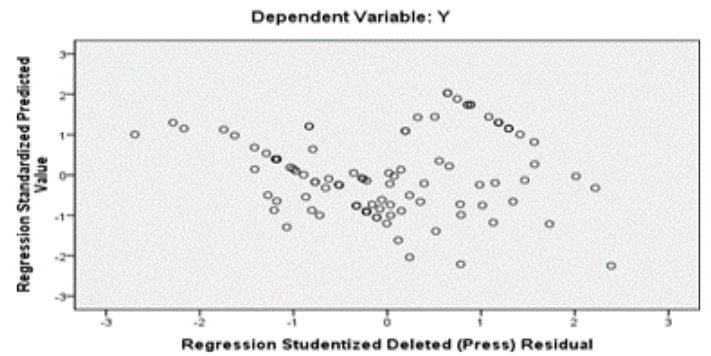

Hasil penelitian pada kuesioner dinyatakan terjadi heteroskedastisitas, apabila variasi variabel satu pengamatan dengan pengamatan yang lain berbeda. Berdasarkan hasil uji heteroskedastisitas pada gambar 2, maka dapat dilihat titik-titik menyebar secara acak pada grafik scatterplot. Dengan demikian dapat dinyatakann bahwa pada penelitian ini tidak terjadi heteroskedastisitas

\section{Hasil Analisis Regresi Linier Berganda}

\begin{tabular}{|c|c|c|c|}
\hline Model & $\begin{array}{c}\text { Unstandardized } \\
\text { Coefficients }\end{array}$ & Nilai $\mathbf{T}$ & Nilai \\
\hline & B & & \\
\hline 1 (Constant) & -8.673 & -.707 & .481 \\
\hline Persepsi Penghargaan Finansial & 1.015 & 3.517 & .001 \\
\hline Pelatihan Profesional & .884 & 3.772 & .000 \\
\hline Nilai-Nilai Sosial & -.569 & -1.254 & .213 \\
\hline Lingkungan Kerja & 1.149 & 2.212 & .029 \\
\hline
\end{tabular}

$$
\begin{aligned}
& \mathrm{Y}=-8.673+1,015 \mathrm{X} 1+0,884 \mathrm{X} 2-0,569 \\
& \mathrm{X} 3+1,149 \mathrm{X} 4+\mathrm{e}
\end{aligned}
$$




$\begin{array}{ll}\text { Dimana : } & \\ \mathrm{a} & : \text { Konstanta } \\ \mathrm{b} 1, \mathrm{~b} 2, \mathrm{~b} 3, \mathrm{~b} 4 & : \text { Koefesien regresi } \\ \mathrm{Y} & : \text { Pemilihan Profesi Akuntan } \\ \mathrm{X} 1 & : \text { Persepsi Penghargaan } \\ & \text { Finansial } \\ \mathrm{X} 2 & \text { : Pelatihan Profesional } \\ \mathrm{X} 3 & \text { : Nilai-nilai Sosial } \\ \mathrm{X} 4 & \text { : Lingkungan Kerja } \\ \mathrm{e} & \text { : Error }\end{array}$

Tabel diatas menunjukkan nilai $\mathrm{R}$ sebesar 0,595 atau 59,5\%. Hal ini berarti bahwa hubungan atau korelasi antara Pemilihan Profesi Akuntan dengan Persepsi Penghargaan Finansial, Pelatihan Profesional, Nilai-nilai Sosial dan Lingkungan Kerja adalah sedang karena berada kisaran 0,40-0,599. Nilai R Square sebesar 0,354 atau 35,4\%, ini menunjukkan bahwa variabel Pemilihan Profesi Akuntan yang dapat dijelaskan oleh variabel Persepsi Penghargaan Finansial, Pelatihan Profesional, Nilai-nilai Sosial dan Lingkungan Kerja adalah sebesar 35,4\%, sedangkan sisanya sebesar 0,646 atau 64,6\% dijelaskan oleh faktor-faktor lain yang tidak disertakan dalam model penelitian ini dari tabel terlihat bahwa thitung koefisien Persepsi Penghargaan Finansial adalah 3.517, sedangkan ttabel bisa dihitung pada tabel t-test, dengan $\alpha=0,05$ karena hipotesis dua arah, ketika mencari ttabel, nilai $\alpha$ dibagi 2 menjadi 0,025 dan $\mathrm{df}=101$ (didapat dari rumus $\mathrm{n}-4$, dimana $\mathrm{n}$ adalah jumlah data, 101-4=97), didapat ttabel adalah 1.985

\section{Pengaruh Persepsi Penghargaan Finansial terhadap Pemilihan Profesi Akuntan. \\ Nilai $t_{\text {hitung }}$ Persepsi Penghargaan} Finansial sebesar 3.517, sementara $t_{\text {tabel }}$ dengan tingkat $\alpha=5 \%$, df $(n-k)=101-4$ didapat nilai $t_{\text {tabel }}$ sebesar 1.985 . Dengan demikian $t_{\text {hitung }}$ Persepsi Penghargaan Finansial $3.517>t_{\text {tabel }} 1.985$ dan nilai sig. $0,001<0,05$ maka dapat disimpulkan bahwa variabel Persepsi Penghargaan Finansial dalam penelitian ini memiliki pengaruh terhadap Pemilihan Profesi Akuntan. Persepsi Penghargaan Finansial mempunyai koefisien regresi kearah Positif sebesar 1,015 (10,15\%). Hal ini berarti jika semakin tinggi nilai Persepsi Penghargaan Finansial menjadi akuntan dalam pandangan mahasiswa, maka hal tersebut akan mempengaruhi keinginan mahasiswa dalam mempertimbangkan kembali untuk memilih Profesinya untuk menjadi Akuntan.

\section{Pengaruh Pelatihan Profesional terhadap Pemilihan Profesi Akuntan. \\ Nilai $t_{\text {hitung }}$ Pelatihan Profesional} sebesar 3.772, sementara $t_{\text {tabel }}$ dengan tingkat $\alpha=5 \%$, df $(\mathrm{n}-\mathrm{k})=101-4$ didapat nilai $\mathrm{t}_{\text {tabel }}$ sebesar 1.985. Dengan demikian thitung Pelatihan Profesional $3.772>\mathrm{t}_{\text {tabel }} 1.985$ dan nilai sig. $0,000<0,05$ maka dapat disimpulkan bahwa variable Pelatihan Profesional dalam penelitian ini memiliki pengaruh terhadap Pemilihan Profesi Akuntan. Persepsi Penghargaan Finansial mempunyai koefisien regresi kearah Positif sebesar $0.884(8,84 \%)$. Hal ini berarti jika semakin rendah Pelatihan Profesional disaat menjadi Auditor dalam pandangan mahasiswa, maka hal tersebut akan mempengaruhi keinginan mahasiswa dalam mempertimbangkan kembali untuk memilih Profesinya untuk menjadi Akuntan.

\section{Pengaruh Nilai-nilai Sosial terhadap Pemilihan Profesi Akuntan.}

Nilai thitung Nilai-nilai sosial sebesar 1.254 , sementara $t_{\text {tabel }}$ dengan tingkat $\alpha=5 \%$, df $(\mathrm{n}-\mathrm{k})=101-4$ didapat nilai $\mathrm{t}_{\text {tabel }}$ sebesar 1.985. Dengan demikian $t_{\text {hitung }}$ Nilai-nilai sosial $-1.254<\mathrm{t}_{\text {tabel }} 1.985$ dan nilai sig. 0,213 $>0,05$ maka dapat disimpulkan bahwa variabel Nilai-nilai sosial dalam penelitian ini tidak memiliki pengaruh terhadap Pemilihan Profesi Akuntan. Nilai-nilai sosial mempunyai koefisien regresi kearah negatif sebesar $-0.569(5,69 \%)$. Hal ini berarti jika semakin rendah atau semakin tinggi Nilainilai sosial seseorang disaat menjadi Auditor dalam pandangan mahasiswa, maka hal tersebut tidak akan mempengaruhi keinginan mahasiswa dalam memilih Profesinya untuk menjadi Akuntan.

\section{Pengaruh Lingkungan Kerja terhadap Pemilihan Profesi Akuntan.}

Nilai $t_{\text {hitung }}$ Lingkungan Kerja sebesar 2.212 , sementara $t_{\text {tabel }}$ dengan tingkat $\alpha=5 \%$, df $(\mathrm{n}-\mathrm{k})=101-4$ didapat nilai $\mathrm{t}_{\text {tabel }}$ sebesar 1.985. Dengan demikian $t_{\text {hitung }}$ Lingkungan kerja $2.212>t_{\text {tabel }} 1.985$ dan nilai sig. $0,029<$ 0,05 maka dapat disimpulkan bahwa variabel Lingkungan Kerja dalam penelitian ini 
memiliki pengaruh terhadap Pemilihan Profesi Akuntan. Lingkungan Kerja mempunyai koefisien regresi kearah Positif sebesar 1,149 (11,49\%). Hal ini berarti jika semakin tinggi situasi tekanan Lingkungan Kerja disaat menjadi akuntan dalam pandangan mahasiswa, maka hal tersebut akan mempengaruhi keinginan mahasiswa dalam mempertimbangkan kembali untuk memilih Profesinya untuk menjadi Akuntan.

\section{KESIMPULAN}

Hasil Penelitian dari pengujian ini menghasilkan bahwa Variabel Persepsi Penghargaan Finansial, Pelatihan Profesional, dan Lingkungan Kerja secara parsial berpengaruh terhadap Pemilihan Profesi Akuntan. Sedangkan variabel NilaiNilai Sosial tidak memiliki pengaruh terhadap Pemilihan Profesi Akuntan.

\section{DAFTAR PUSTAKA}

Abbas, Dirvi Surya, Basuki Basuki, and Muhammad Rifai. "Pengaruh Persepsi Penghargaan Finansial Dan Nilai-Nilai Sosial Terhadap Pemilihan Profesi Akuntan (Mahasiswa Prodi Akuntansi UMT)." Simposium Nasional Mulitidisiplin (SinaMu) (2019).

Abbas, Dirvi Surya, and Basuki Basuki. "PENGARUH PROFESIONALIME AUDITOR DAN PENGALAMAN AUDITOR TERHADAP AUDIT JUDGEMENT (KAP Provinsi Banten)." Simposium Nasional Mulitidisiplin (SinaMu) (2019).

Avianti, Ilya. 2015. Peluang dan Tantangan Akuntan di Era MEA. Simposium Nasional Akuntansi (SNA) XVIII. Medan, 17 September 2015

Ambari dan Ramantha. (2017). PERTIMBANGAN PASAR KERJA, PENGAKUAN PROFESIONAL, NILAI-NILAI SOSIAL, LINGKUNGAN KERJA, PERSONALITAS PEMILIHAN KARIR SEBAGAI AKUNTAN PUBLIK. E-Jurnal Akuntansi Universitas Udayana, 18, 705-734.

Choirunisa, S. A. (2017). PENGARUH PENGHARGAAN FINANSIAL, GENDER DAN LINGKUNGAN KERJA TERHADAP MINAT MENJADI AKUNTAN PEMERINTAH.

Efendi, R. (2018). PENGARUH PERSEPSI PENGHARGAAN FINANSIAL, PELATIHAN PROFESIONAL, NILAINILAI SOSIAL, DAN LINGKUNGAN
KERJA TERHADAP PEMILIHAN PROFESI AKUNTAN PADA MAHASISWA PROGRAM STUDI AKUNTANSI FAKULTAS EKONOMI UNIVERSITAS NEGERI YOGYAKARTA.

Ghozali, I. (2011). Aplikasi Analisis Multivariate dengan Progam IBM SPSS 19.

Iswahudin, M. (2015). PENGARUH PENGHARGAAN FINANSIAL DAN PERTIMBANGAN PASAR KERJA TERHADAP PEMILIHAN PROFESI SEBAGAI AKUNTAN PROFESIONAL.

Naminingsih, N. N. (2018). PENGARUH PENGHARGAAN FINANSIAL, PELATIHAN PROFESIONAL, PENGAKUAN PROFESIONAL, PERTIMBANGAN PASAR,TEMAN DAN KELUARGA DALAM PEMILIHAN KARIR AKUNTAN PUBLIK.

R Antares. (2019). Jumlah Akuntan Indonesia Masih Minim di Tingkat ASEAN. Tagar News. Retrieved from https://www.tagar.id/jumlah-akuntanindonesia-masih-minim-di-tingkatasean

Rahmawati, K. (2014). Pemilihan karier akuntan publik: Pengaruh penghargaan finansial, orientasi etika, pengakuan profesional dan pelatihan profesional. $1-20$.

Riyanto, R. A. (2015). ANALISIS FAKTORFAKTOR YANG MEMPENGARUHI MINAT MAHASISWA AKUNTANSI BERKARIR MENJADI AKUNTAN PUBLIK. NASKAH PUBLIKASI, 3(2), 54-67.

Sulistyawati, A. I. (2013). PERSEPSI MAHASISWA AKUNTANSI MENGENAI FAKTOR-

FAKTOR YANG MEMPENGARUHI PEMILIHAN KARIR. Jurnal Dinamika Akuntansi, 5(2), 86-98.

Zaid, M. I. (2015). Pengaruh Gender, Penghargaan Finansial, dan Pertimbangan Pasar Kerja terhadap Minat Mahsiswa Akuntansi untuk Berkarier Menjadi Akuntan Publik (Studi Kasus pada Mahasiswa Akuntansi Universitas Negri Yogyakarta).

Ramdani, R.F., dan Zulaikha. (2013). Analisis Faktor - Faktor yang Mempengaruhi Pemilihan Karir Mahasiswa Akuntansi. Diponegoro Jurnal Of Accounting.Vol. 2, No. 4, 1-13

Kharismawati, Happy. 2015. Analisis Pengaruh Penghargaan Finansial, 
Pelatihan Profesional Pengakuan Profesional, Nilai-Nilai Sosial Dan Lingkungan Kerja Terhadap Pemilihan Karir Akuntan Publik (Studi Empiris Pada Mahasiswa Ppak Di Uns, Ugm Dan Stie Ykpn). Naskah Publikasi. Program Studi Akuntansi Fakultas Ekonomi Dan Bisnis. Universitas Muhammadiyah Surakarta

\section{Dari internet}

http://iaiglobal.or.id/v03/beritakegiatan/detailberita-936=tantanganbesar-dunia- akuntansi-di-era-digital-- (Tulisan ini telah terbit di Majalah Akuntan Indonesia Edisi April - Juni 2016

kompasiana.com/kasriana/5c32972812ae944c 377c61a8/ancaman-atau-peluanggenerasi- 4-0-bagiakuntansi?page=2. 7 Januari 2019 